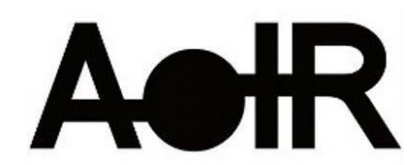

Selected Papers of \#AoIR2021:

The 22nd Annual Conference of the

Association of Internet Researchers

Virtual Event / 13-16 Oct 2021

\title{
“DO YOUR RESEARCH”: COVID-19 AND THE NARRATIVE OF INFORMATION INDEPENDENCE AMONG CZECH INSTAGRAM INFLUENCERS
}

Marie Heřmanová

Institute of Sociology, Czech Academy of Sciences

\begin{abstract}
The global pandemic in 2020 significantly reshaped influencer culture worldwide as travel restrictions and the closure of many public places such as pubs and cafés limited the options for what constituted aspirational content (Hund et al 2019) in the prepandemic world. While social media influencers undoubtedly play an important role in spreading awareness and sometimes vital information about covid-related situation to their audience (Abidin et al 2020) there's also evidence of Instagram and TikTok influencers involvement in the spread of conspiracies and false information regarding the pandemic (Maly 2020) and of the role that Instagram influencers played in the mainstreaming of QAnon-related narratives in the US (Remski, 2020). The proliferation of political narratives on Instagram is thus an ongoing trend, accelerated by the pandemic, but most likely here to stay, as Instagram evolves and competes with other (re)emerging platforms.
\end{abstract}

The aim of the paper is to analyse the role of lifestyle Instagram influencers in shaping the public narrative that explains COVID-19 as an orchestrated political event aimed at curbing civic freedom in the Czech Republic. The narrative of COVID-19 as political cause is often placed in the context of post-socialist historical experience of the Czech citizens, where the invocation of totalitarian past has a highly symbolic discursive value - in this context, the anti-pandemic restrictions are discussed as a return to authoritarian communist state (closed borders and the restrictions on freedom of movement and right to assembly are the most discussed markers of the perceived return of the past).

Suggested Citation (APA): Heřmanová, M. (2021, October). Do Your Research: COVID-19 and The Narrative of Information Independence Among Czech Instagram Influencers. Paper presented at AolR 2021: The 22nd Annual Conference of the Association of Internet Researchers. Virtual Event: AolR. Retrieved from http://spir.aoir.org. 
The paper attempts to identify the role lifestyle influencers may have played in the proliferation of the distrustful narrative (and subsequently in the formation of negative attitudes towards vaccination). Empirically it builds on long-term digital ethnography (participant and non-participant observation at the platform, semi-structured narrative interviews) among a group of 15 Czech female influencers aged 23 to 35 . The focus of the analysis is on two key elements in the process of the narrative shaping and proliferation:

1 - The shift in the both the self-perception and public perception of lifestyle influencers from aspirational celebrities towards opinion leaders via the process of "politicization of the domestic" on Instagram. While the role of platforms such as Facebook, Twitter and YouTube has been widely discussed and researched in the context of political communication and its actors (for example Finlayson 2020, Štětka et al 2019 in the Czech context), Instagram on the other hand has until recently been suspiciously absent from these debates. In the public imagination Instagram tends to be perceived as female dominated space for aspirational lifestyle content where politics is intentionally overlooked, even though evidence shows that Instagram has been used for spreading disinformation in 2016 US presidential election, to mention one example (Howard et al 2018, Leaver at al 2020). The gendered character of influencers' work on social media (Duffy 2016, Duffy and Hund 2019) often leads to the assumption that politics, seen as male domain, is excluded from the influencer communities on Instagram. Social media on the other hand offered women an unprecedent tool of political expression, where the dedication to the domestic affairs could be seen as a political act on itself (Stern, 2020) and female political activists have been able to utilize their platform in novel ways, proliferating political content via connecting it to everyday lifestyle choices and domestic issues (Miller-Idriss, 2020). The paper argues that the pandemic further blurred the boundaries between domestic and political on Instagram because "staying at home" was performed as an expression of political opinion and the everyday lifestyle decisions such as where to play with children or where and how to shop for groceries could be used to demonstrate a political stance towards the government-imposed restrictions. The female lifestyle influencers used their platforms to chronicle these now politicized everyday decisions and to subsequently communicate their opinion to their followers. They also started openly discussing their political opinions to justify their actions when facing critique.

The concept of "third space" developed by Scott Wright seems to be particularly useful in the context of the discussed data. Wright defines "third spaces" as non-political online spaces where political talk emerges. Women seek refuge in primarily non-political places because the openly political online arenas discussion are often dominated by men and perceived as unsafe. Women are often actively discouraged to participate in the discussion by men and are targets of sexist attacks and various forms of hatespeech (Vochocová 2018, Jane 2014, Poletta and Chen, 2013). In this sense, female influencers aim at creating "third spaces" within the communities of their followers on Instagram where they feel safe to discuss their attitudes towards the pandemic openly.

2 - The shift from domestic to political on Instagram needs to be explained in the context of historical experience of (post)socialism in the Central and Eastern European region. Previous research (Heřmanová and Lehečka 2016) indicated that the distrust of 
mainstream media narratives in the post-socialist space is often framed by what is perceived as mainstream media hegemony and the need to "do your research" before forming an opinion. Influencers are adapting to this context by placing themselves as the ones who are "doing their own research" and present information filtered through everyday reality of average citizen as opposed to elitist journalists or politicians. While the hashtag \#doyourownresearch has been in the English-speaking context recently associated with the spread of QAnon conspiracy, its Czech variations used among lifestyle influencers often point to the perceived media hegemony which is seen as a dangerous return of past totalitarian practices of the state. Within this context, the influencers are positioning themselves as the independent voice of the public and thus an important democratic element in the pandemic situation.

\section{References}

Abidin, C., Barbetta, T. \& Lee, J. (2020). Influencers, Brands, and Pivots in the Time of COVID-19: A Look at Australian, Japanese, and Korean Issues. M/C Journal, 23(6). https://doi.org/10.5204/mcj.2729

Finlayson, A. (2020). YouTube and Political Ideologies: Technology, Populism and Rhetorical Form. Political Studies. https://doi.org/10.1177/0032321720934630

Duffy, B.E. (2016). The romance of work: Gender and aspirational labour in the digital culture industries. International Journal of Cultural Studies 19(4): 441 - 457.

https://doi.org/10.1177/1367877915572186

Duffy, B. E., \& Hund, E. (2019). Gendered Visibility on Social Media: Navigating Instagram's Authenticity Bind. International Journal of Communication, 13(0), 20.

Hund, E., McGuigan, L (2019) A Shoppable Life: Performance, Selfhood, and Influence in the Social Media Storefront, Communication, Culture and Critique, 12 (1) 2019, P. 18-35, https://doi.org/10.1093/ccc/tcz004

Heřmanová, M., Lehečka, M. (2016) The roots and causes of Czech attitudes towards migration - audience research report, Anthropictures, available at:

http://www.anthropictures.cz/, (retrieved 1.4.2021)

Howard, P.N., Ganesh, B., Liotsiou, D., Kelly, J. and Francois, C. (2018). The IRA, Social Media and Political Polarization in the United States, 2012 - 2018.

Computational Propaganda Research Project, Oxford University

Leaver, T., Highfield, T. and Abidin, C. (2020). Instagram. Polity Press.

Maly, I. (2020). Metapolitical New Right Influencers: The Case of Brittany

Pettibone. Soc.Sci. 9 (113) https://doi.org/10.3390/socsci9070113

Miller-Idriss, C. (2020). Hate in the Homeland - The New Global Far Right. Princeton University Press.

Polletta F and Chen PCB (2013) Gender and public talk: Accounting for women's variable participation in the public sphere. Sociological Theory 31(4): 291-317 
Stern, A.M. (2020). Living the TradLife: Babies, Butter, and the Vanishing of Bre Faucheux, in Stern, A.M. (2020) Proud Boys and the White Ethnostate: How the Altright is Warping the American Imagination, Beacon Press.

Štětka, V., Surowiec, P., \& Mazák, J. (2019). Facebook as an instrument of election campaigning and voters' engagement: Comparing Czechia and Poland. European Journal of Communication, 34(2), 121-141. https://doi.org/10.1177/0267323118810884

Vochocová, L., \& Rosenfeldová, J. (2019). Ridiculed, but safe: What e-mothers' discussion on migration tells us about the potential of 'third spaces' for the political communication of women. European Journal of Communication, 34(2), 142-158. https://doi.org/10.1177/0267323118810865

Wright, S. (2012). From "third place" to "third space": Everyday political talk in nonpolitical online spaces. In Javnost (Vol. 19, Issue 3, pp. 5-20). EURICOM. https://doi.org/10.1080/13183222.2012.11009088 